\title{
Analisis Penyebab Kejadian dan Evaluasi Bencana Tanah Longsor di Desa Banaran, Kecamatan Pulung, Kabupaten Ponorogo, Provinsi Jawa Timur Tanggal 1 April 2017
}

\author{
Heru Sri Naryanto ${ }^{1}$, Hasmana Soewandita1, Deliyanti Ganesha ${ }^{1}$, Firman \\ Prawiradisastra $^{1}$, dan Agus Kristijono ${ }^{1}$ \\ 1Pusat Teknologi Reduksi Risiko Bencana (PTRRB), Badan Pengkajian dan Penerapan Teknologi (BPPT), \\ Gedung Geostech, Kompleks Puspiptek, Serpong, Kota Tangerang Selatan / Gedung 2 BPPT, Lantai 12, Jl. \\ MH Thamrin 8, Jakarta 10340 \\ e-mail: heru.naryanto@bppt.go.id
}

\begin{abstract}
ABSTRAK
Bencana tanah longsor di Indonesia semakin sering terjadi dari tahun ke tahun.Bencana tanah longsor telah terjadi di Dusun Tangkil, Desa Banaran, Kecamatan Pulung, Kabupaten Ponorogo, Provinsi Jawa Timur pada tanggal 1 April 2017. Lokasi tanah longsor di Desa Banaran, Kecamatan Pulung, Kabupaten Ponorogo, Jawa Timur, terletak pada zona kerentanan tinggi. Tipologi tanah longsor berupa longsoran bahan rombakan,yang kemudian ke arah bawah (Sungai Tangkil) berkembang menjadi tipe aliran bahan rombakan. Faktor-Faktor yang berpengaruh terhadap terjadinya tanah longsor lokasi penelitian adalah: kelerengan, batuan dan tanah, rekahan/retakan batuan, konversi lahan, drainase dan keairan, curah hujan tinggi, dan aktivitas manusia. Dari kesemuanya faktor-faktor tersebut, yang paling dominan dan berpengaruh terhadap tanah longsor adalah: lereng yang sangat curam, soil hasil pelapukan sangat gembur dan tebal, alih fungsi lahan dan curah hujan yang tinggi. Material longsoran tidak terkonsolidasi dengan baik sehingga masih mudah bergerak, dan kemungkinan pembendungan pada Sungai Tangkil oleh material longsoran tersebut bisa berpotensi terjadinya banjir bandang. Beberapa permukiman yang berada di sekitar lokasi longsor mempunyai risiko tinggi dan sedang terhadap longsor, sehingga perlu dibangun kesiapsiagaan masyarakat, pembangunan sistem peringatan dini longsor serta untuk jangka panjang adalah relokasi jika memang kondisi semakin parah.Pertanian lahan kering pada lereng-lereng sebaiknya menggunakan pola agroforestry. Kawasan sub DAS berisiko longsor, sebaiknya dikembalikan fungsi lahan sebagai hutan konservasi atau hutan lindung seperti sebelumnya.
\end{abstract}

Kata kunci: longsor, Ponorogo, sangat curam, soil tebal, degradasi lahan, curah hujan tinggi, risiko

\begin{abstract}
Landslides in Indonesia are becoming increasingly frequent from year to year.A landslide disaster has occurred in Tangkil, Banaran Village, Pulung Sub-District, Ponorogo District, East Java Province on April 1, 2017. The location of landslides in Banaran Village, Pulung Sub-District, Ponorogo District, East Java, lies in the high vulnerability zone. The landslide typology is a debris slide, which then in the downstream direction (Tangkil River) develop into a type ofdebris flow. Factors that influence the occurrence of landslides in the study area are:very steep slope, rock and soil, fracture, land conversion, drainage and irrigation, high rainfall, and human activities. Of all the influential factors, the most dominant factors for landslides are: steep slopes, weathered soil is very loose and thick,land conversion, and high rainfall. Landslide material is not well consolidated so that it is still easy to move, and the possibility of damming the Tangkil River by landslide material can potentially cause flash floods. Some settlements located near landslide locations have high and moderate risks of landslides, so community preparedness needs to be built, the establishment of landslide early warning systems and long-term relocation if the condition is getting worse. Dryland farming on slopes should use agroforestry patterns. Sub-watershed areas are at risk of landslides, the land should be restored as conservation forest or protected forest as before.
\end{abstract}

Keywords: landslide, Ponorogo, steep slopes, thick soil, land degradation, high rainfall, risk

Citation: NaryantoH.S., Suwandita' H., Ganesha' D., Prawiradisastra' F., dan Kristijono, A.(2019). Analisis Penyebab Kejadian dan Evaluasi Bencana Tanah Longsor di Desa Banaran, Kecamatan Pulung, Kabupaten Ponorogo, Provinsi Jawa Timur Tanggal 1 April 2017. Jurnal Ilmu Lingkungan, 17(2), 272-282, doi:10.14710/jil.17.2.272-282 


\section{Pendahuluan}

Bencana tanah longsor atau sering disebut gerakan tanah semakin sering terjadi di Indonesia dari tahun ketahun. Tanah longsor merupakan salah satu kejadian alam yang terjadi di wilayah peggunungan, terutama di musim hujan. Kondisi tektonik di Indonesia yang membentuk morofolagi tinggi, patahan, batuan vulkanik yang mudah rapuh serta ditunjang dengan iklim di Indonesia yang berupa tropis basah, sehingga menyebabkan potensi tanah longsor menjadi tinggi.Hal ini ditunjang dengan adanya degradasi perubahan tataguna lahan akhir-akhir ini, menyebabkan kejadian tanah longsor menjadi semakin meningkat.Kombinasi faktor antropogenik dan alam sering merupakan penyebab terjadinya longsor yang memakan korban jiwa dan kerugian harta benda.(Naryanto, 2013; Naryanto, 2017).Wang et al.(2017)mengatakan bahwa kejadian tanah longsor berhubungan dengan berbagai faktor seperti presipitasi, geologi, jarak dari patahan, vegetasi, dan topografi.

Tanah longsor adalah proses perpindahan massa batuan (tanah) akibat gaya berat (gravitasi). Longsor terjadi karena adanya gangguan kesetimbangan gaya yang bekerja pada lereng, yaitu gaya penahan dan gaya peluncur. Gaya peluncur dipengaruhi oleh kandungan air, berat massa tanah itu sendiri berat beban bangunan. Ketidakseimbangan gaya tersebut diakibatkan adanya gaya dari luar lereng yang menyebabkan besarnya gaya peluncur pada suatu lereng menjadi lebih besar daripada gaya penahannya, sehingga menyebabkan massa tanah bergerak turun (Naryanto, 2011; Naryanto et al., 2016).

Tanah longsor terjadi karena dua faktor utama yaitu faktor pengontrol dan faktor pemicu.Faktor pengontrol adalah faktor-faktor yang memengaruhi kondisi material itu sendiri seperti kondisi geologi, kemiringan lereng, litologi, sesar dan kekar pada batuan.Faktor pemicu adalah faktor yang menyebabkan bergeraknya material tersebut seperti curah hujan, gempabumi, erosi kaki lereng dan aktivitas manusia (Naryanto, 2013; Naryanto, 2017). Tanah longsor adalah bencana alam yang mengakibatkan hilangnya nyawa manusia dan menyebabkan kerusakan luas pada properti dan infrastruktur.Tanah longsor, secara umum mencakup semua gerakan ke bawah atau tiba-tiba material permukaan seperti tanah liat, pasir, kerikil dan batu.Tanah longsor merupakan salah satu bencana utama yang merusak di daerah pegunungan, yang diaktifkan karena pengaruh gempa bumi dan curah hujan (Pareta\& Pareta, 2012).

Tingginya tingkat kerugian yang dialami oleh masyarkat yang diakibatkan karena terjadinya bencana alam disebabkan karena kurangnya informasi yang diperoleh masyarakat akan kemungkinan kemungkinan bencana yang terjadi disekitarnya, sehingga kesadaran masyarakat akan tanggap bencana menjadi sangat minim. Oleh karena itu, informasi awal mengenai potensi dan risiko bencana merupakan salah satu media informasi yang dapat digunakan sebagai pendidikan dasart anggap bencana bagi masyarakat (Damanik, 2012; Rahmad et al., 2018).

Yuniarta et al. (2015) mengatakan bahwa Kabupaten Ponorogo merupakan daerah yang berpotensi mengalami kejadian tanah longsor karena bentuk morfologi banyak berupa perbukitan. Data tersebut didapatkan dari analisis GIS dengan menggunakan banyak parameter yang ditumpangsusunkan (overlay) kemudian diberi pembobotan (skor). Dari hasil penelitian tersebut menunjukkan bahwa Kabupaten Ponorogo dapat dikategorikan sebagai daerah dengan kondisi tanah longsor agak rawan di daerah perbukitan dan pegunungan, sedangkan pada bagian dataran rendah sebagai daerah sedikit rawan.

Bencana tanah longsor telah melanda Dusun Tangkil, Desa Banaran, Kecamatan Pulung, Kabupaten Ponorogo, Provinsi Jawa Timur pada hari Sabtu 1 April 2017, jam 08.00 WIB, pada saat masyarakat sudah melakukan aktivitas bekerja di kebun masing-masing. Berdasarkan data dari Badan Penanggulangan Bencana Daerah (BPBD) Kabupaten Ponorogo (2017), dilaporkan 6 orang korban meninggal, 22 orang belum ditemukan akibat tertimbun tanah longsor, dan 17 orang luka ringan. Korban yang tertimbun longsor yang berasal dari warga yang berada di dalam rumah dan bekerja memanen jahe saat longsor berlangsung.

Lokasi tanah longsor di Desa Banaran terletak pada zona kerentanan tinggi berdasarkan Peta Zona Gerakan Badan Geologi dari Pusat Vulkanologi dan Mitigasi Bencana Geologi (PVMBG) (2009).Zona Kerentanan Tinggi merupakan daerah yang berpotensi untuk terjadi gerakan tanah.Jika terjadi hujan dengan intensitas dan durasi yang lama, gerakan tanah lama bisa aktif kembali.

Tulisan ini bertujuan untuk mengetahui fenomena kejadian tanah longsor, faktor-faktor yang berpengaruh terhadap kejadian longsor, faktorfaktor dominan, mekanisme kejadian, risiko masyarakat yang berada di sekitar lokasi longsor serta rekomendasi pengurangan risiko bencana tanah longsor yang diperlukan.

\section{Metode Penelitian}

\subsection{Lokasi Penelitian}

Lokasi tanah longsor di Desa Banaran, Kecamatan Pulung, Kabupaten Ponorogo, Jawa Timur.Penelitian dilakukan pada bulan April 2017, dimulai pada dua hari pasca kejadian bencana tanah longsor di kawasan tersebut padatanggal 1 April 2017.

\subsection{Metode Pengumpulan Data}

Metode pengumpulan data yang dilakukan adalah sebagai berikut:

- Koordinasi dengan instansi terkait, yaitu Badan Nasional Penanggulangan Bencana (BNPB), BPBD Kabupaten Ponorogo, Badan Meteorologi Klimatologi dan Geofisika (BMKG), PVMBG, Universitas, serta Kementerian/Lembaga terkait. 
- Kajian referensi/data sekunder berkaitan dengan bencana longsor di Dusun Tangkil, Desa Banaran, Kecamatan Pulung, Kabupaten Ponorogo, Provinsi Jawa Timur. Data sekunder mencakup kajian penelitian terdahulu tentang longsor yang terjadi, termasuk tentang daerah/lokasi, waktunya, catatan-catatan instansi terkait, cerita penduduk, geologi, geomorfologi, struktur geologi, geologi tata lingkungan, geologi teknik, foto udara curah hujan, DAS dan sub DAS, keairan, sosial ekonomi, tata ruang / RTRW, penggunaan lahan, penduduk dan lain-lain geologi tata lingkungan, geologi teknik, foto udara, peta struktur geologi, peta jenistanah, peta landsystem, Kabupaten Ponorogo dalam Angka dan lain-lain.

- Survei lapangan pasca bencana tanah longsor secara komprehensif. Survei pasca longsor meliputi pengamatan dampak kejadian, luasan, kemiringan lereng, topografi, jenis litologi, pengukuran kekuatan tanah, tataguna lahan, kondisi hidrologi, curah hujan, mataair, sub DAS, tataguna lahan, jenis vegetasi, sosial ekonomi masyarakat, diskusi dengan masyarakat setempat/korban, pemetaan longsor dan analisis mekanisme longsor pendahuluan, serta pemetaan dengan drone.

\subsection{Metode Analisis Data}

\subsubsection{Analisis Spasial}

Analisis spasial dilakukan pada lokasi penelitian dengan tahapan proses sebagai berikut:

- Analisis peta sub DAS dengan melakukan pengolahan data kontur rupabumi BIG skala 1:25.000 melalui software Global Mapper.

- Analisis peta kemiringan lereng dengan melakukan pengolahan data kontur rupabumi BIG skala 1: 25.000 melalui extension spatial analyst pada software ArcGIS 10.6.

- Analisis overlay data spasial infrastruktur jalan, sungai, sub DAS dan citra World Imagery dengan menggunakan software Global Mapper untuk mengetahui kondisi tata ruang sebelum terjadi longsor.

- Analisis peta penggunaan lahan dengan menggunakan citra hasil drone melalui software ArcGIS 10.6 untuk delinisasi wilayah terdampak longsor pada lokasi penelitian, sehingga dapat diidentifikasi sebaran permukiman, kerusakan akibat longsor dan untuk dasar penataan kawasan selanjutnya.

\subsubsection{Analisis Data Fotogrametri dengan Drone}

Salah satu metoda pengumpulan data adalah dengan pembuatan foto udara menggunakan drone, untuk mendapatkan data lokasi survei. Dalam kegiatan tersebut digunakan dronetipe DJI Inspire. Pengambilan data dengan menggunakan kamera digital: compact, mirrorless, SLR, built-in. Pengumpulan data juga dilakukan dengan melihat data peta yang dapat diakses dan digunatakan seperti googlemap, applemap, maverick dan data peta lainnya. Pemrosesan data otomatis sepenuhnya dengan perangkat lunak pix4dmapper dan agisoft photoscan. Alur metode pembuatan foto udara dengan drone adalah: penetapan lokasi target, pembuatan rencana terbang, pengambilan data dengan drone, pengolahan data dengan drone, pembuatan kontur dan pembuatan peta.

\subsubsection{Analisis Mekanisme Longsor}

Berbagai parameter dalam analisis mekanisme kejadian longsor tersebut adalah: kondisi geologi, topografi, tataguna lahan, curah hujan, keairan dan drainase dan pengaruh aktivitas manusia. Analisis mekanisme kejadian longsor sangat penting untuk pembelajaran dalam mengantisipasi kejadian serupa pada lokasi sekitar atau tempat lain.

\section{Hasil dan Pembahasan}

\subsection{Tipologi Tanah Longsor}

Tipe tanah longsor yang terjadi berupa longsoran bahan rombakan (debris slide) berbentuk rotasi, yaitu gerakan massa tanah yang membentuk cekungan

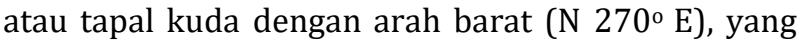
kemudian ke arah bawah longsoran berbelok ke arah selatan melewati saluran air yang berkembang menjadi tipe aliran bahan rombakan (debris flow) akibat bercampur dengan masa air dalam jumlah besar dan menjadi lumpur. Aliran bahan rombakan secara aktif bergerak mengikuti aliran Sungai Tangkil, dan dalam beberapa hari material longsor selalu bergerak khususnya apabila jumlah air sangat banyak (Gambar 1 dan 2).

\subsection{Faktor-Faktor Penyebab Terjadinya Tanah Longsor di Dusun Tangkil, Desa Banaran \\ 3.2.1. Kelerengan}

Secara umum, geomorfologi terbentuk oleh perbukitan sedang sampai terjal. Di bagian lereng dan bawah perbukitan ini dipergunakan sebagai tempat pemukiman penduduk dan perkebunan. Pengamatan pada puncak mahkota longsor di Dusun Tangkil, Desa Banaran, ditunjukkan tebing dengan kelerengan sekitar 70-140\%, yang termasuk katagori sangat curam(very steep) menurut klasifikasi Zuidam (1985)(Tabel 1). Kemiringan lereng di bawahnya lebih landai lagi yang digunakan untuk permukiman dan perladangan. Ketinggian mahkota longsor adalah 990-1.010 meter di atas permukaan laut (dpal). Jarak antara mahkota longsor dengan titik akhir terpanjang ke arah barat laut sekitar 1.500 meter.Arah dari posisi tengah mahkota longsor ke arah selatan dan berbelok ke arah timur.

Keterbatasan data topografi yang detail sebelum kejadian longsor menyebabkan kendala dalam interpretasi. Berdasarkan pengolahan kontur yang diperoleh dari data rupabumi skala 1:25.000 tahun 2016 maka dapat diidentifikasi wilayah ketinggian dan kemiringan lereng sebelum terjadi longsor. Ketinggian di lokasi longsor dan sekitarnya terbagi menjadi 4 kelas yaitu 0-800 m, 800-900 m, 900-1000 m dan 1000-1200 m. Lokasi longsor didominasi oleh ketinggian 800-900 meter. 
Sedangkan permukiman di sekitar lokasi longsor berada di wilayah ketinggian 900-1000 meter.

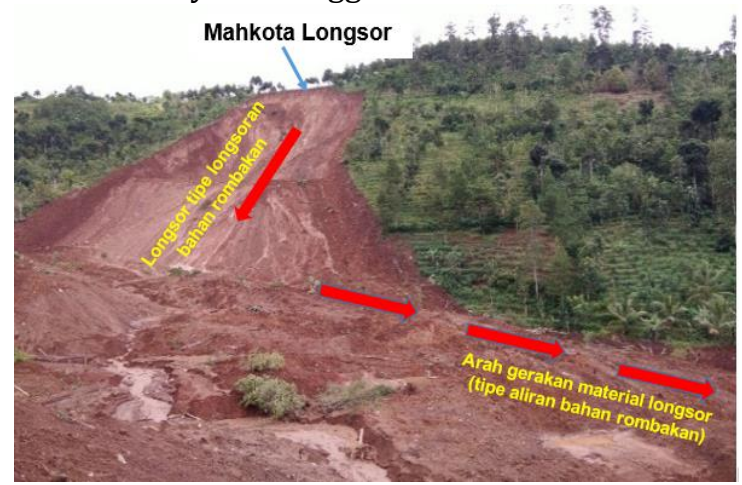

Gambar1. Tanah longsor di Dusun Tangkil, Desa Banaran yang Berbelok Setelah Menabrak Bukit di Bawahnya

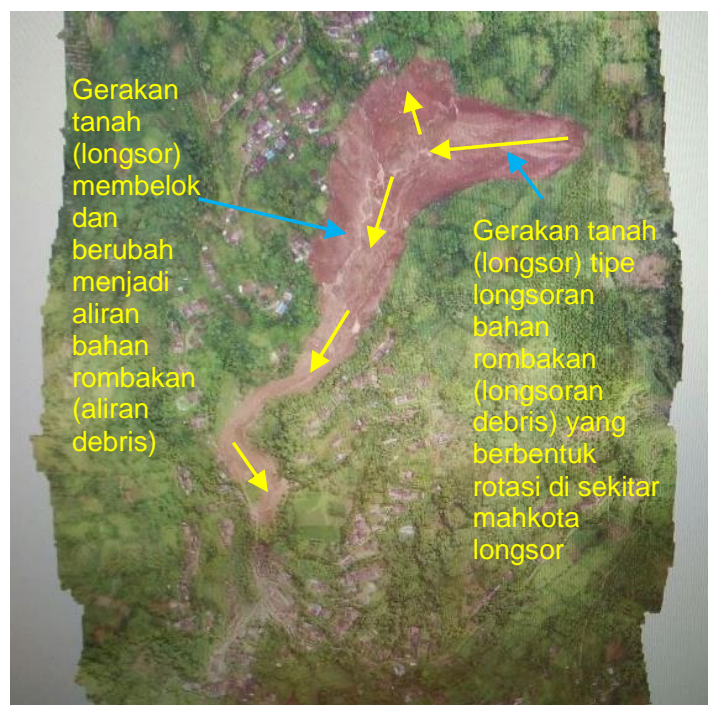

Gambar 2. Gambaran Tipologi Longsoran Bahan Rombakan yang ke Arah Bawah Berbelok dan Berkembang Menjadi Aliran Bahan Rombakan (Sumber: Analisis Data dan Foto Diambil dari BNPB)

Tabel 1. Klasifikasi Kemiringan Lereng Menurut Zuidam (1985)

\begin{tabular}{|c|c|c|c|}
\hline Kelas & $\begin{array}{l}\text { Kemiringan } \\
\text { Lereng (\%) }\end{array}$ & Slope $\left({ }^{\circ}\right)$ & Klasifikasi \\
\hline 1 & $0-2$ & $0-1.15$ & Datar (flat to almost flat) \\
\hline 2 & $2-7$ & $1.15-4$ & $\begin{array}{l}\text { Agak landai (gentle } \\
\text { sloping) }\end{array}$ \\
\hline 3 & $7-15$ & $4-8.5$ & Landai (sloping) \\
\hline 4 & $15-30$ & $8.5-16.7$ & $\begin{array}{c}\text { Agak curam (moderately } \\
\text { steep) }\end{array}$ \\
\hline 5 & $30-70$ & $16.7-35$ & Curam (steep) \\
\hline 6 & $70-140$ & $35-54.5$ & Sangat curam (very steep) \\
\hline 7 & $>140$ & $>54.5$ & $\begin{array}{c}\text { Curam ekstrim(extremely } \\
\text { steep) }\end{array}$ \\
\hline
\end{tabular}

Keterbatasan data topografi yang detail sebelum kejadian longsor menyebabkan kendala dalam interpretasi. Berdasarkan pengolahan kontur yang diperoleh dari data rupabumi skala 1:25.000 tahun 2016 maka dapat diidentifikasi wilayah ketinggian dan kemiringan lereng sebelum terjadi longsor. Ketinggian di lokasi longsor dan sekitarnya terbagi menjadi 4 kelas yaitu 0-800 m, 800-900 m, 900-1000 $\mathrm{m}$ dan 1000-1200 m. Lokasi longsor didominasi oleh ketinggian 800-900 meter. Sedangkan permukiman di sekitar lokasi longsor berada di wilayah ketinggian 900-1000 meter.

Kondisi kemiringan lereng pada lokasi longsor sangat bervariasi. Berdasarkan klasifikasi Zuidam (1985), maka kemiringan lereng pada lokasi longsor dan sekitarnya terdiri dari 5 wilayah yaitu 0 $2 \%$ (datar), 2-7\% (agak landai), 7-15\% (agak curam), $15-30 \%$ (curam) dan 30-70\% (sangat curam).

Interpretasi kemiringan lereng sebelum terjadi longsor pada lokasi longsor dilakukan dengan cara mempelajari dan mengestimasi melalui pengolahan data kontur RBI dan membandingkannya dengan data drone. Berdasarkan analisis data tersebut maka dapat disimpulkan bahwa kemiringan lereng lokasi longsor dengan permukiman di lokasi longsor tersebut didominasi lereng sangat curam. Kondisi ketinggian dan kemiringan lereng pada lokasi kejadian tanah longsor bisa dilihat pada Gambar 3 dan 4.

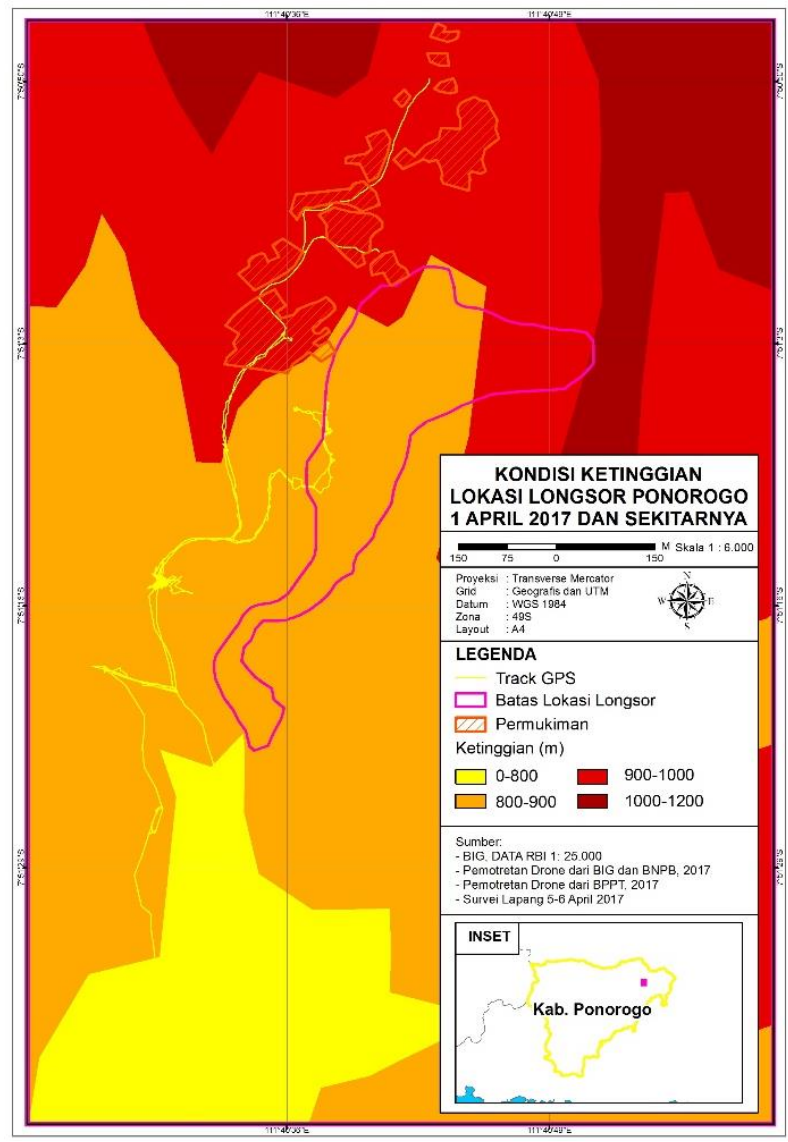

Gambar 3. Kondisi Ketinggian di Lokasi Longsor dan Sekitarnya (Sumber: Analisis Data)

\subsubsection{Batuan dan Tanah/Pelapukan Batuan}

Menurut peta geologi dari Sampurno \& Samodra (1997), batuan yang terdapat di Dusun Tangkil, Desa Banaran, Kecamatan Pulung, Kabupaten Ponorogo terbentuk oleh Satuan Morfoset Jeding-Paukbanteng (Qj),yang terdiri dari lava andesit piroksen, breksi gunung api/breksi vulkanik dan sisipan tuf dan batu apung. Lereng tersebut tersusun dari batuan gunungapi yang bersifat urai 
dan banyak retakan, serta menumpang pada batuan sedimen tersier yang dapat membentuk bidang gelincir.

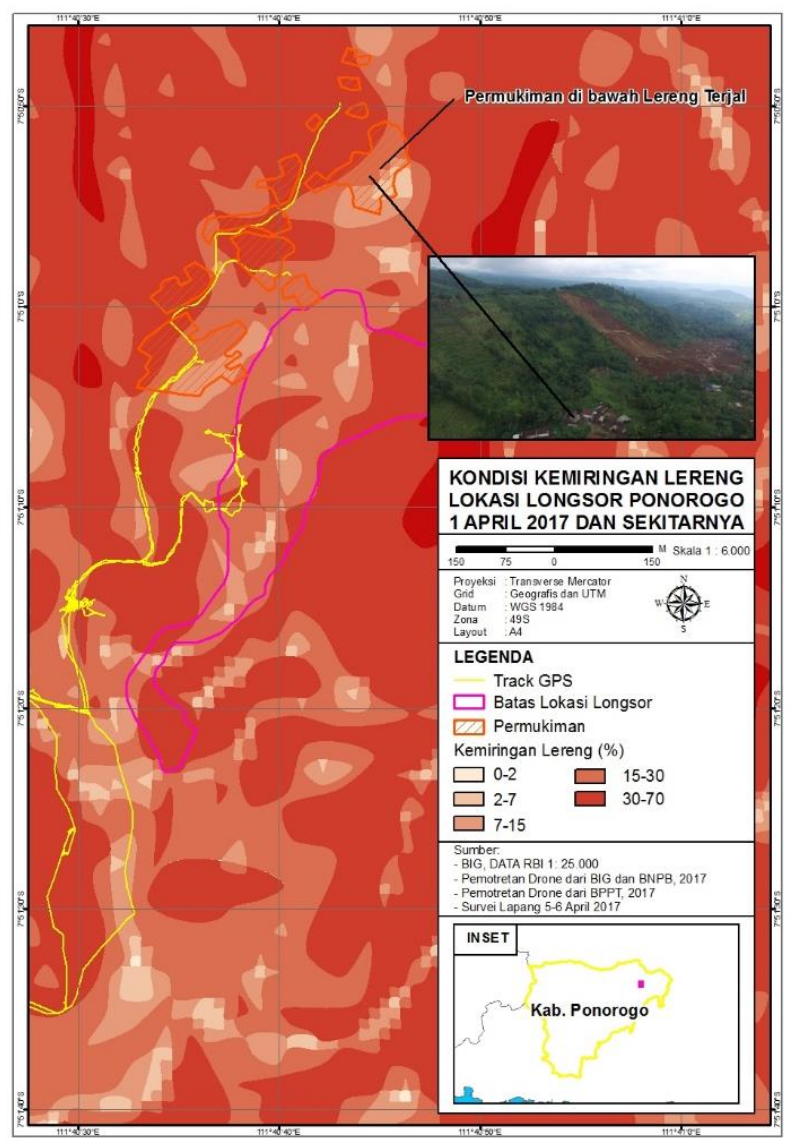

Gambar 4. Kondisi Kemiringan Lereng di Lokasi Longsor dan Sekitarnya (SRTM 30m) (Sumber: Analisis Data)

Batuan penutup berupa soil di bagian atas, berasal dari pelapukan batuan breksi vulkanik. Breksi vulkanik banyak mengandung tufa dan material lain yang mudah mengalami pelapukan, sehingga bisa membentuk soil dengan ketebalannya lebih dari 7 meter.Sifat fisik tanah pelapukan berupa lempung pasiran sampai, gembur, tidak kompak dan mudah lepas.Lapisan soil kemudian bergradasi ke batuan breksi vulkanik yang relatif tidak terlapukan di bagian bawahnya (ukuran komponen antara pasir sampai dengan bongkah, besar komponen rata-rata sekitar 5-10 cm; dengan matriks pasir haluslanau).Di bagian bawah material lapuk (soil) yang berupa batuan breksi vulkanik, terdapat bidang batas antara batuan lunak dan batuan keras yang berfungsi sebagai bidang gelincir longsor apabila terjadi kejenuhan akibat masuknya air ke dalam pori-pori tanah.

Tipe tanah pada lapisan atas mempunyai warna yang lebih gelap, mengindikasikan kandungan bahan organiknyayang tergolong tinggi, solum tanah juga tebal, sehingga tanah ini tergolong mempunyai kesuburan yang baik.Kondisi ini yang menyebabkan tekanan akitivitas manusia (petani) untuk budidaya pertanian baik tanaman semusim ataupun tanaman tahunan.Kondisi sifat fisik tanah mempunyai tekstur lempung berdebu hingga lempung liat berpasir, struktur remah dan gembur, serta tanah mempunyai kesuburan yang cukup baik juga merupakan salah satu pilihan petani untuk melakukan aktivitas budidaya tanaman khususnya jahe dan kacang tanah.

\subsubsection{Retakan Batuan}

Sebelum kejadian longsor biasanya didahului dengan terbentuknya retakan atau rekahan batuan yang terjadi di bagian atas mahkota longsor.Pertengahan bulan Maret 2017, warga Dusun Tangkil sudah melihat rekahan/retakan batuan yang terjadi di bagian atas mahkota longsor.Dijumpai adanya rekahan di atas bukit yang longsor sebagai pertanda terjadinya ketidakstabilan lereng.Rekahan ini menyebabkan air hujan yang jatuh dapat lebih mudah untuk meresap ke dalam tanah dan mempermudah terjadinya kejenuhan tanah.Menurut PVMBG (2017), daerah kejadian tanah longsor merupakan zona lemah, yang diperkirakan terdapat struktur patahan atau sesar.

Informasi dari warga setempat, retakan awal sekitar $30 \mathrm{~cm}$ sebelumnya telah dideteksi di lokasi longsor, setiap hari bertambah sekitar $8 \mathrm{~cm}$ hingga $10 \mathrm{~cm}$. Kepala Desa telah mengintruksikan Jogoboyo (keamanan kampung) untuk memantau retakan tanah di Bukit Gede setiap harinya. Sejak saat itu, warga pun diminta untuk waspada mengingat potensi longsor Bukit Gede dapat terjadi kapan saja.Warga juga telah dihimbau untuk mengungsi ke pemukiman warga lainnya yang lebih tinggi dan jauh dari jarak Bukit Gede. Himbauan untuk mengungsi telah dilakukan warga dan dilaksanakan pada malam hari, sementara pada pagi hingga siang warga kembali ke pemukimannya (Naryanto et al., 2017).

\subsubsection{Penggunaan Lahan}

Morfologi lahan sekitar lokasi longsor di Desa Banaran Kecamatan Pulung Kabupaten Ponorogo merupakan perbukitan bergunung.Pada bagian lembah yang sempit mengalir sungai dengan pola aliran yang berasal atau hulunya dari lereng lereng perbukitan tersebut.Pada bagian bukit atau gunung kelerengan lahannya sangat curam.Sedangkan lebar lembahnya tergolong sempit yang sebagian dimanfaatkan untuk kawasan permukiman penduduk.

Dengan topografi dan kelerengan tergolong sangat curam, namun lereng lereng perbukitan yang terjal ini dimanfaatkan oleh masyarakat/petani untuk aktivitas budidaya pertanian, mengingat tanahnya tergolong gembur dan subur. Model pertanian sudah menerapkan konsep mikro konservasi (terasering) dengan lebar teras hanya berkisar 1 hingga maksimal $3 \mathrm{~m}$.Karakteristik sifat tanah yang gembur menyebabkan daya serap/infiltrasi yang sangat efektif bagi air hujan.Pola sistem budidaya Jahe disinyalir turut menjadi pemicu pintu masuk air bisa terserap kedalam tanah secara efektif.Pada saat menanam tanah dilubangi, sementara pada saat pertumbuhan perakaran/buah akanmenembus tanah dengan mudah karena tanah gembur. Begitu selanjutnya pada saat menjelang 
panen rumpun jahe sudah mati sehingga tutupan lahan oleh tajuk daun akan berkurang, kondisi ini yang turut berkontribusi tanah akan melewatkan air kebawah dengan mudah.

\section{a. Kawasan hutan}

Berdasarkan kondisi morfologi lahan, lahan sekitar lokasi longsor merupakan kawasan dengan morfologi berbukit hingga bergunung dengan kemiringan lereng lebih dari $60^{\circ}$. Kawasan ini secara fungsi hidroorologis sebenarnya merupakan kawasan lindung. Nampak bahwa masih tersisa hutan pinus yang berada pada puncak bukit, sementara pada bagian lereng sudah berubah fungsi menjadi kawasan budidaya tanaman semusim denganpola tumpangsari(multiple cropping) tanaman keras.Tanaman keras lainnya yang dibudidayakan dan tersisa adalah tanaman mahoni, sengon, jati, waru dan cengkeh.

\section{b. Kawasan budidaya dan vegetasi}

Tata guna lahan eksisting dilokasi longsor sebagian besar merupakan kawasan budidaya tanaman semusim yang terhampar pada lereng bukit membentuk teras teras searah kontur. Lokasi ini pada awalnya merupakan hutan lindung dan pada lokasi puncak sekitarnya masih tersisa tanaman keras seperti hutan pinus dibawah konsesi Perum Perhutani.Kawasan hutan yang merupakan kawasan lindung ini terdesak oleh aktivitas kegiatan manusia yaitu budidaya tanaman semusim mengingat kondisi tanahnya yang tergolong subur.

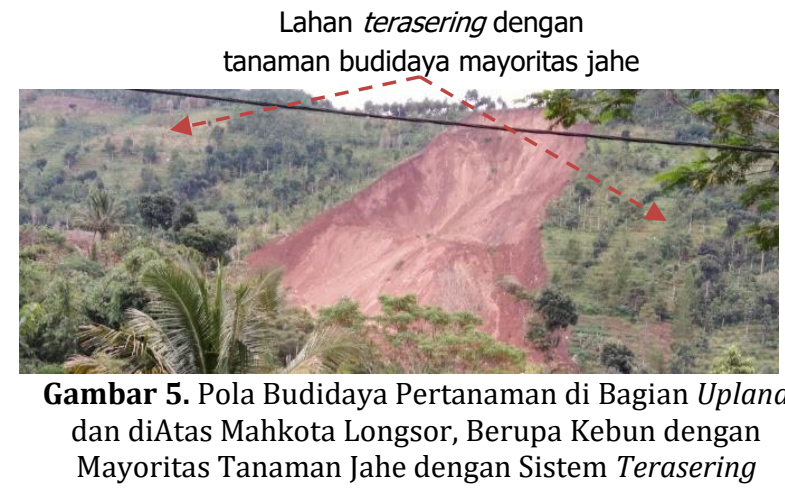

Meskipun merupakan perbukitan dengan kelerengan yang tergolong sangat curam, perbukitan di sekitar lokasi kejadian bencana longsor telah dimanfaatkan untuk budidaya tanaman khususnya tanaman jahe.Dari segi aspek konservasi tanah, lahan dengan kelerengan sangat curam tidak cocok untuk budidaya tanaman dan harus merupakan kawasan konservasi/lindung. Namun apabila dilihat dari areal terdampak longsor morfologi lahan pada kaki bukit relatif mempunyai kemiringan lereng tidak terlalu curam.Pada lahan ini dimanfaatkan untuk persawahan padi sawah pada kaki bukit hingga pertengahan dan pada kawasan yang lebih atas (upland), lahan dimanfaatkan untuk pertanian tegalan dan pola pertanian agroforestry(Gambar 5).

Berdasarkan peta penggunaan tanah diketahui bahwa penggunaan tanah di lokasi longsor dan sekitarnya menurut data peta RBI Skala 1:25.000 BIG adalah perkebunan (jahe, jati, kelapa, kebun campuran), permukiman dan agrikultur lahan kering. Pada mahkota longsor dan perbukitan di sebelahnya memang memiliki sedikit pohon pohon besar namun dominan masih ditutupi oleh perkebunan dan agrikultur lahan kering (Gambar 6).

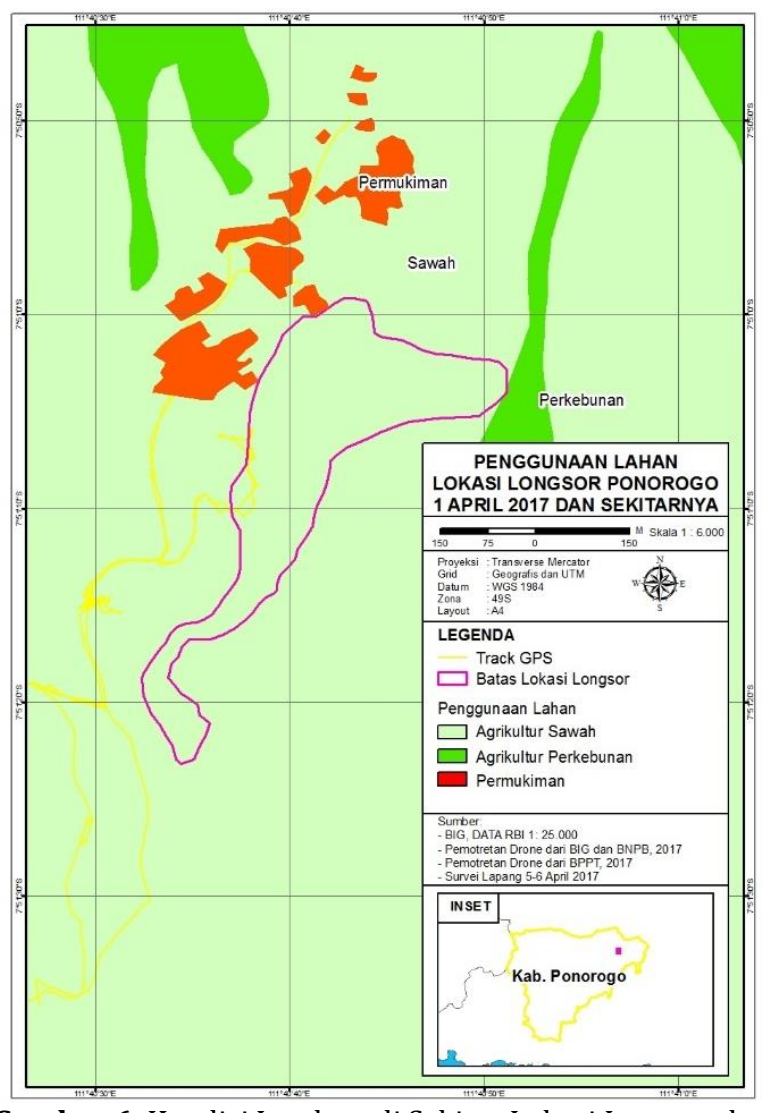

Gambar 6. Kondisi Landuse di Sekitar Lokasi Longsor dan Sekitarnya (Sumber: Analisis Data)

\subsubsection{Drainase dan Keairan}

Terdapat drainase alami yaitu Sungai Tangkil yang berada dan mengalir pada kaki perbukitan atau pada lembah lokasi longsor.Aliran air ini sebagian berasal atau hulunya berada pada bukit yang longsor tersebut. Nampak juga aliran air tertoreh pada area potongan longsoran sebagai bentuk jalan aliran air yang keluar dari badan bukit yang terlepas/terpotong karena longsor.Jalur pola drainase permukaan juga nampak pada kerapatan tanaman keras yang tumbuh memotong kontur dan ini sebagai bentuk drainase yang dibuang dari lereng lereng yang berteras pada kegiatan budidaya tanaman semusim.Drainase yang berpola vertikal memotong kontur/lereng ada kecenderungan membentuk parit yang berfungsi membuang kelebihan air/run off dari lereng lereng yang tidak terinfiltrasi pada lahan budidaya. 
Mata air kecil terbentuk pada bagian atas dan tengah bukit Gunung Gede, kelihatan pada saat kejenuhan air sangat tinggi.Dari kejauhan terlihat adanya torehan-torehan pada tebing longsor membentuk alur-alur baik di bagian bawah mahkota longsor.Sistem drainase ini mengumpulkan kelebihan air dilahan dan membuangnya dalam arah horizontal searah kontur dan tegak lurus kontur.Sistem ini disebut juga parit yang secara tidak langsung dibuat oleh petani lahan dalam rangka membuat guludan atau petakan lahan. Pada bagian tengah bukit juga nampak aliran air yang mengalir liar terbuang kebawah melewati alur alami diantara reruntuhan tanah pasca terjadinya longsor, dan makin ke bawah makin besar mengalir ke sungai dibagian barat yang debitnya cukup besar. Sementara itu lahan pada kaki bukit ditunjang oleh sistem drainase yang sekaligus berfungsi sebagai saluran irigasi untuk budidaya pertanian padi sawah (Gambar 7 dan 8) (Naryanto et al., 2017).

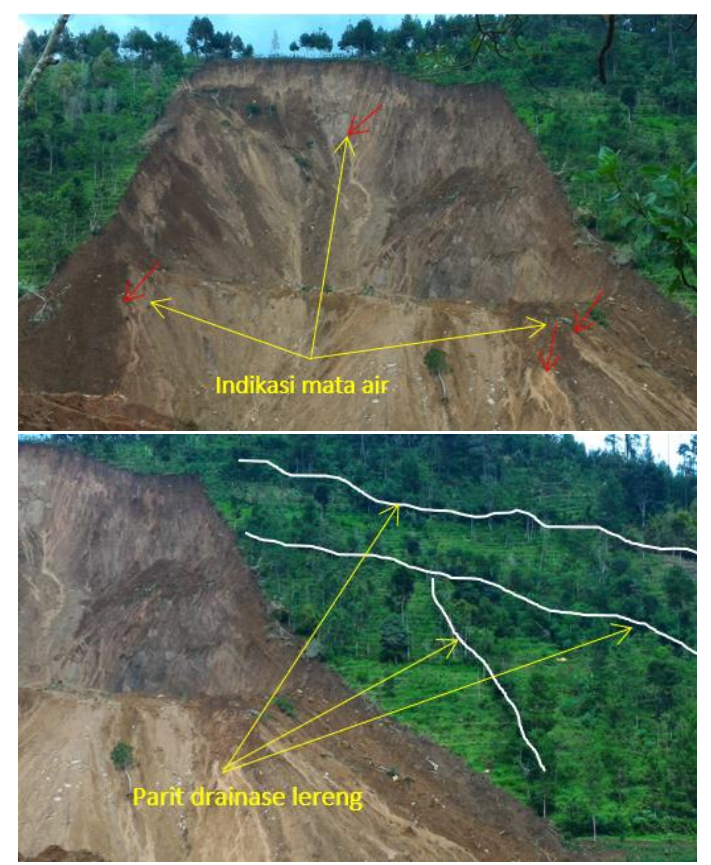

Gambar 7. Indikasi Mata Air yang Muncul dari Lereng Potongan Longsor dan Parit Drainase Lereng Area Budidaya

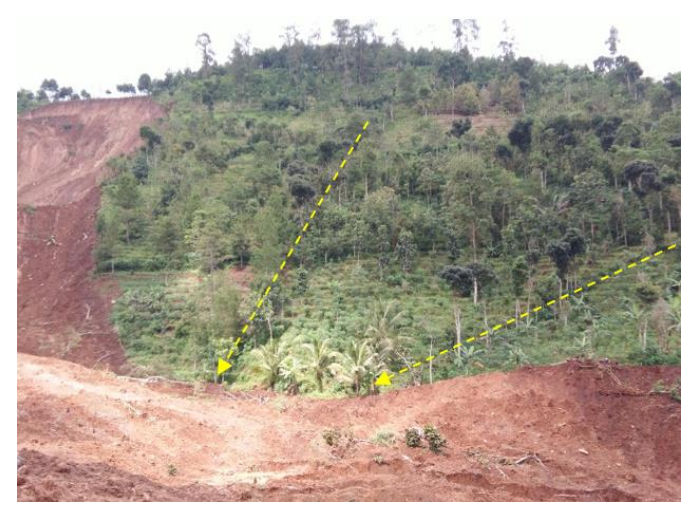

Gambar 8. Alur Parit di Bagian Lahan Upland

Analisis hasil dari kajian tanah longsor dilakukan dengan menggunakan nano cell, yaitu analisis dengan pendekatan sub DAS-sub DAS kecil yang ada di lokasi longsor dan sekitarnya sehingga keluaran menjadi lebih detail dan fokus pada cell yang berisiko tinggi terkena longsor. Pada peta sub DAS dibuat dengan akumulation aliran 10 hektar yang memperlihatkan sub DAS yang berada pada lokasi longsor dan arah aliran sungai yang searah dengan pergerakan longsor (Gambar 9).

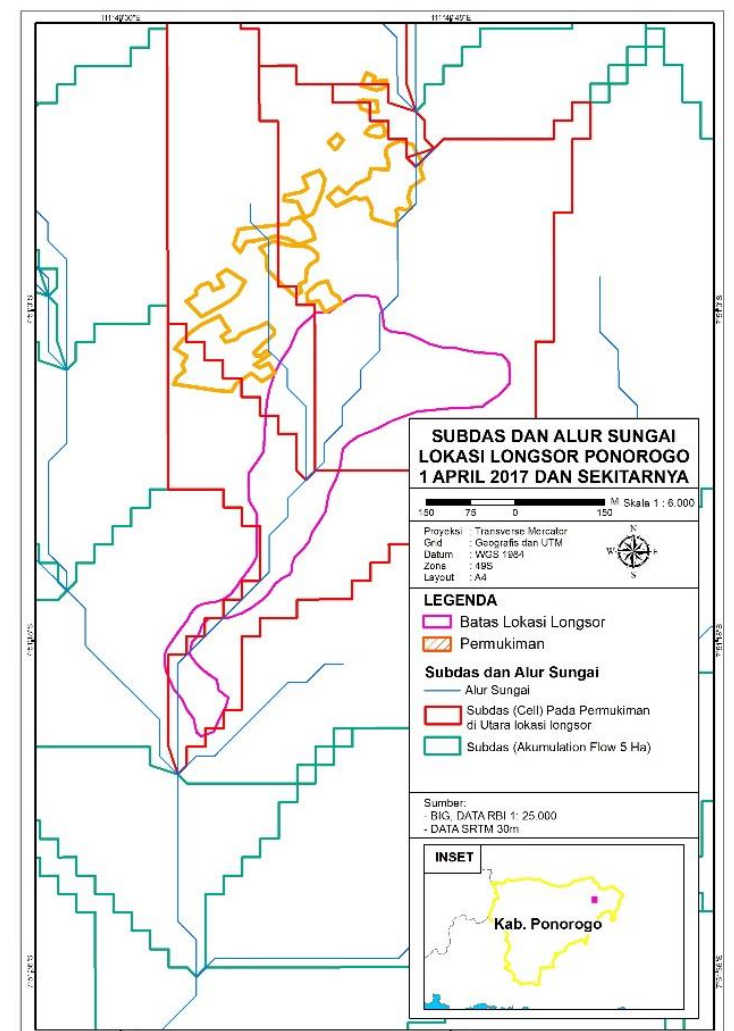

Gambar 9. Sub DAS pada lokasi longsor (Sumber: Analisis Data)

\subsubsection{Curah Hujan}

Kondisi curah hujan sangat ekstrim menjadi salah satu pemicu bencana tanah longsor di di Desa Banaran, Kec.Pulung.Curah hujan tinggi telah terjadi pada hari-hari sebelum terjadi longsor.Pemicu longsor besar di Desa Banaran adalah tingginya curah hujan yang ada di sekitar kawasan lokasi bencana.Hujan bahkan diinformasikan mengguyur selama tiga hari sebelum kejadian secara terusmenerus dengan intensitas tinggi.Sehari sebelum kejadian itu hujan terjadi mulai dari sore hingga tengah malam.Kondisi itu memicu terjadinya serapan air dalam tanah cukup tinggi, sehingga tanah dalam kondisi jenuh air.

\subsubsection{Aktivitas Manusia}

Faktor manusia dibeberapa bencana memang seringkali menjadi faktor kunci terjadinya bencana.Terutama untuk bencana tanah longsor. Ketidakseimbangan tanah akibat salah pengelolaan budidaya manusia yang secara kumulatif dapat memicu terjadi longsor yang sangat membahayakan dikemudian hari. Berdasarkan hasil pengamatan lapangan, data sekunder, dan wawancara dengan warga yang menjadi saksi mata terjadinya bencana 
longsor di Dusun Tangkil, secara sosial kultural kepala keluarga yang tertimbun longsor memilki mata pencaharian bertani, khususnya tanaman jahe, selain padi sawah, jagung, sengon, rumput gajah, kopi, kakao, bambu, sayur-sayuran dan lain-lain. Mereka bertani di sekitar rumahnya dan rata-rata bukan petani penggarap melainkan mereka bertani di lahan milik mereka sendiri. Selain bertani mata pencaharian penduduk Dusun Tangkil ini adalah bekerja di kampung lain, namun jumlahnya hanya sedikit. Sebagian warga Dusun Tangkil tertimbun longsor karena kejadian longsor yang diikuti aliran bahan rombakan, lokasi permukimannya sebagian besar berada pada sepanjang aliran sungai di bawah longsor.

\subsection{Faktor Paling Dominan yang Berpengaruh Terhadap Tanah Longsor}

Dari pembahasan di atas, banyak faktor-faktor yang mempengaruhi terjadinya tanah longsor, tetapi dari hasil analisis faktor-faktor utama yang berpengaruh terhadap bencana tanah longsor di Dusun Tangkil, Desa Banaran ada empat (4), yaitu :

a. Topografi pada sumber terbentuknya tanah longsor mempunyai kelerengan sangatcuram.

b. Batuan breksi vulkanik yang mudah lapuk yang membentuk soil hasil pelapukan sangat tebal (lebih dari 7 meter), mempunyai sifat menyerap air sangat tinggi sehingga mudah jenuh dan membuat ketidakstabilan lereng.

c. Pemanfaatan lahan terasering dengan tanaman hortikultura terutama tanaman jahe, memerlukan upaya penggemburan tanah untuk kesuburan sehingga menyebabkan mudahnya terjadinya resapan tanah sampai terjadi kejenuhan tanah yang memudahkan terjadinya ketidakstabilan lereng.

d. Curah hujan yang memiliki intensitas lama yang terjadi pada hari-hari dan beberapa jam sebelum terjadinya tanah longsor.

\subsection{Analisis Mekanisme Terjadinya Tanah Longsor}

Berdasarkan pengamatan di lapangan serta informasi yang didapat dapat diintepretasikan mekanisme terjadinya longsor di Dusun Tangkil, Desa Banaran adalah sebagai berikut:

a. Batuan breksi vulkanik yang membentuk perbukian yang sangat curam, telah membentuk soil atau tanah hasil pelapukan batuan yang sangat tebal. Dijumpai adanya rekahan/retakan di atas bukit yang longsor sebagai pertanda ketidakstabilan lereng. Rekahan ini menyebabkan air hujan yang jatuh dapat lebih mudah untuk meresap ke dalam tanah dan mempercepat kejenuhan tanah. Komposisi breksi andesit yang sebagian mempunyai fragmen batuan andesit yang sangat kompak, pembentukan undakan longsor kemungkinan besar terganjal oleh batuan kompak dan sangat massif dari batuan andesit tersebut.

b. Lokasi longsor di Dusun Tangkil, Desa Banaran secara umum terletak pada morfologi yang terjal. Pada lokasi awal di mahkota longsor terbentuk oleh kemiringan lereng yang ekstrim.

c. Lahan yang mendominasi kawasan lereng dan bagian puncak bukit bersifat mudah menyerap air tanah yang berasal dari air hujan sehingga aliran air relatif lebih lancar terus masuk ke lapisan soil. Pada bagian atas dan samping mahkota longsor kelihatan rekayasa terasering untuk pemanfaatan lahan tanaman jahe, yang seharusnya bisa dijadikan hutan dengan akar yang kuat. Air hujan yang masuk melalui rekahan maupun melalui proses infiltrasi biasa kemudian menjenuhkan tanah penutup hingga ke batuan breksi vulkanik. Di dasar longsor terlihat jelas jenis batuannya yaitu breksi vulkanik yang masih keras. Karena curah hujan tinggi, tanah mudah menjadi jenuh dan breksi tersebut semakin jenuh dengan air dan air tidak dapat terinfiltrasi lebih jauh karena keras dan bidang batas tersebut berfungsi sebagai bidang gelincir.

d. Pemicu utama dari kejadian bencana tanah longsor tersebut adalah curah hujan tinggi. Hujan yang turun terus menerus selama beberapa jam sebelum terjadinya longsor menyebabkan air permukaan meresap masuk ke dalam tanah/batuan melalui retakan/rekahan dan ruang antar butir tanah/batuan yang sudah terbentuk sebelumnya, sehingga tanah/batuan menjadi jenuh air, menyebabkan bobot masanya dan tekanan air pori bertambah serta kuat gesernya menurun.

e. Tanah yang mengandung air menjadi semakin jenuh, oleh karenanya mengakibatkan pula semakin berat massanya. Tekanan hidrostatis diperkirakan timbul pada batas antara lapisan soil yang jenuh air dengan lapisan breksi vulkanik yang relatif kedap air. Terbentuknya batuan kedap air dan tanah yang jenuh, menyebabkan lapisan kedap air yang berupa batuan breksi vulkanik menjadi bidang gelincir dari tanah penutup di atasnya, sehingga memicu ketidak seimbangan pada lereng dan terjadi gerakan massa tanah tersebut.

f. Hujan yang menerus mengakibatkan sebagian air tertahan di bagian atas dan tengah tubuh longsor dan membentuk kejenuhan yang luar biasa pada tanah (soil). Air semakin lancar masuk ke dalam pori-pori tanah sampai batas kontak dengan batuan dasarnya. Pada saat beban massa tanah sudah lewat maka kestabilan lereng terganggu dan longsor dahsyat terjadi sekitar pada hari Sabtu tanggal 1 April 2017 jam 08.00 WIB. Longsor tipe longsoran bahan rombakan menyebabkan getaran yang sangat keras dirasakan penduduk karena massa yang longsor yang bergerak sangat banyak menghantam bagian depan arah longsor yang mengenai bukit dan berbelok mengalir ke selatan melalui lembah Sungai Tangkil ke arah hilir yang berubah menjadi tipe aliran bahan rombakan (debris). Semakin banyak air yang terkandung di dalamnya, maka semakin tinggi kecepatan aliran debris bergerak. 


\subsection{Permukiman yang Berisiko Terhadap Bencana Longsor}

Permukiman dengan risiko tinggi berada persis di bawah lereng terjal sama seperti kondisi permukiman pada lokasi longsor dulu sebelum kejadian longsor. Gambar 10 berikut ini merupakan kondisi sebelum longsor dari LAPAN yang berasal dari citra SPOT-6 dengan tanggal akuisisi 23 Februari 2017.

Kondisi fisik di sekitar permukiman tersebut juga paling mirip dengan kondisi lokasi longsor sebelum terjadi longsor. Kedua lokasi tersebut juga berlereng curam mirip dengan lokasi permukiman yang berada persis di bawah lereng terjal, memiliki formasi batuan yang terdiri dari tufa yang bersifat mudah lapuk, curah hujan yang sama dengan lokasi longsor dan penggunaan tanah yang sudah banyak terjadi bukaan lahan seperti perkebunan jahe, perkebunan campuran, permukiman dan agrikultur lahan kering.

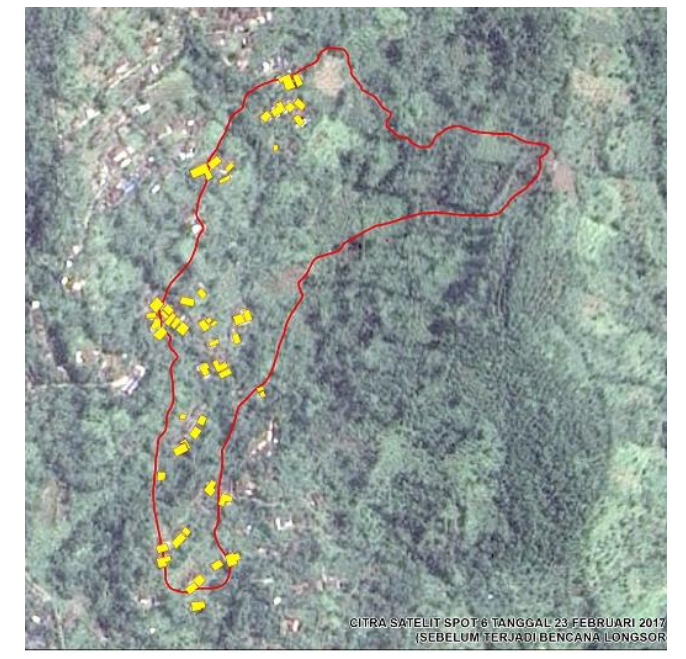

Gambar 10. Kondisi Daerah Sebelum Terjadi Longsor (Sumber: Analisis Data Berdasarkan Citra SPOT-6 LAPAN)

Berdasarkan peta risiko longsor, dapat diketahui pada permukiman dengan risiko longsor tinggi diberi simbol berwarna merah dan berada persis di sebelah utara lokasi longsor dan sejajar dengan lokasi longsor.Sedangkan permukiman dengan risiko longsor sedang diberi simbol warna oranye dan lokasinya sebagian besar berada di barat laut lokasi longsor.

Hasil pemetaan fotogrametri dan survei lapang dengan menggunakan Drone dapat diolah menjadi data kontur sehingga didapatkan kondisi topografi lapangan secara detail dan deliniasi permukiman yang lokasinya mirip dengan lokasi longsor tersebut. Data ketinggian yang diperoleh dari SRTM 30m didetailkan dengan data ketinggian dari Drone. Berikut ini pemetaan ketinggian dan kemiringan lereng yang berasal dari data SRTM 30m dan data Drone. Berdasarkan peta ketinggian dari drone maka dapat diketahui klasifikasi ketinggian pada permukiman di utara lokasi longsor berkisar antara 800-1.074 m dpl. Permukiman tersebut dominan berada di perbukitan yang memiliki ketinggian 940-980 m dpl.

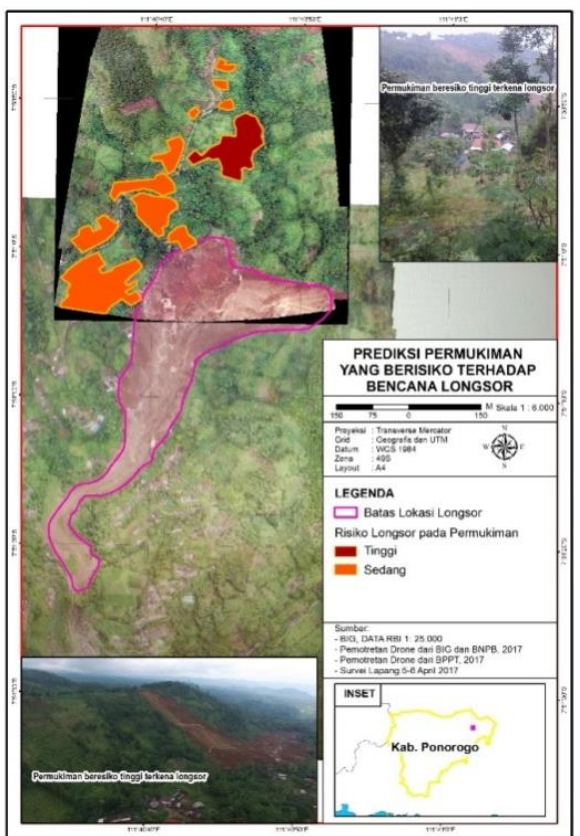

Gambar 11. Permukiman yang Berada Sekitar Longsor yang Berisiko Tinggi
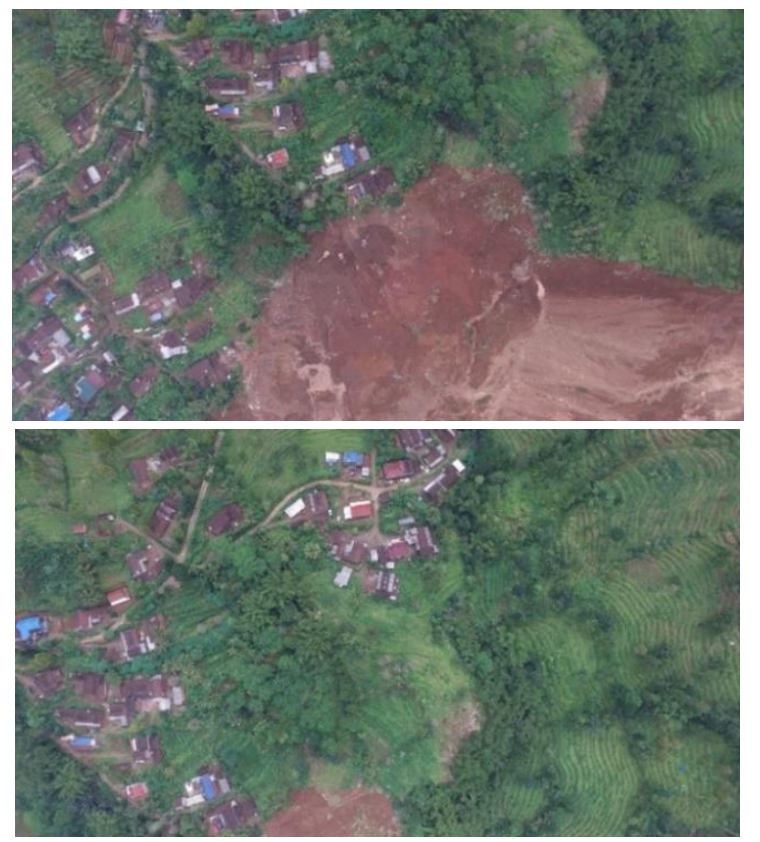

Gambar 12. Beberapa Foto dengan Menggunakan Drone di Sekitar Lokasi Longsor dan Bagian Utaranya (Sumber: Analisis Data Drone)

Berdasarkan peta kemiringan lereng dari data drone maka lokasi permukiman di utara lokasi longsor berada di wilayah kemiringan lereng $0-45^{\circ}$ dan dominan berada di lereng yang terjal. Permukiman tersebut ada yang berada persis di lereng yang terjal dan ada juga yang berada persis di bawah lereng terjal. Permukiman tersebut berada di lereng terjal dan memiliki kondisi fisik yang sama dengan lokasi longsor yang terjadi. Peta kondisi fisik lainnya seperti geologi dan penggunaan lahan dapat dilihat pada pembahasan berikutnya. Gambar 11 menunjukkan permukiman yang berada di bawah 
lereng terjal pada sekitar lokasi longsor dan peta kemiringan lereng.

Berdasarkan analisis data drone, maka dapat diketahui kemiringan lereng pada permukiman di utara lokasi longsor secara detail didominasi kelerengansangat curam. Data ini dijadikan acuan untuk perkiraan kelas lereng pada lokasi sebelum longsor.Berdasarkan data SRTM 30m maka dapat diketahui kemiringan lereng pada sekitar permukiman di utara lokasi longsor mirip dengan kemiringan lereng pada lokasi longsor (Naryanto et al., 2017).

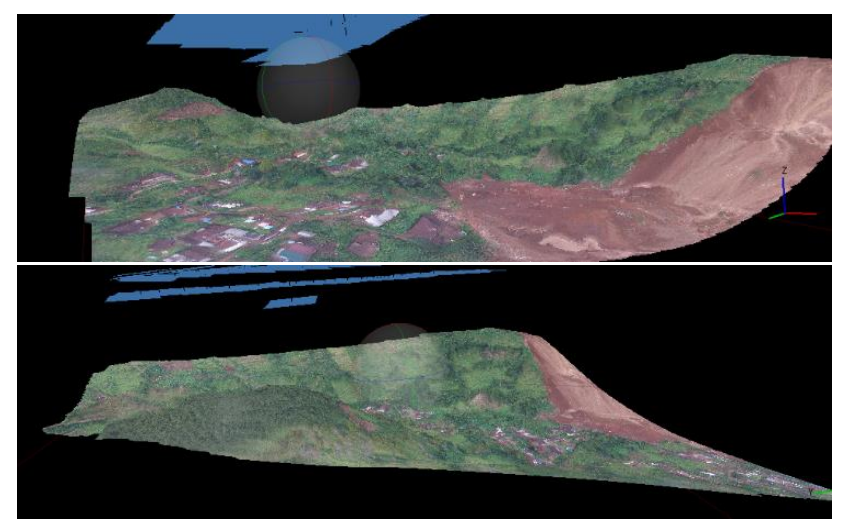

Gambar 13. Topografi dalam Bentuk 3 Dimensi pada Daerah Longsor dan Permukiman di Sekitarnya yang juga Terancam Berdasarkan Pengolahan Data Drone (Sumber: 4. Analisis Data)

\subsection{Pengurangan Risiko Bencana Tanah Longsor di Dusun Tangkil, Desa Banaran}

Kondisi biofisik lahan di Dusun Tangkil, Desa Banaran yang berpotensi besar terhadap bencana tanah longsor, memerlukan upaya mitigasi yang tepat agar korban jiwa dan kerugian material dapat dikurangi. Perubahan tataguna lahan telah terjadi di kawasan tersebut pada tahun-tahun terakhir ini. Pada kawasan rawan longsor perlu dijadikan lahan perkebunan dengan tanaman keras yang berakar kuat dan dalam yang berfungsi dapat menahan lereng. Tanaman keras pada lereng yang sudah ada sebaiknya tidak dilakukan penebangan, kalau terpaksa harus dilakukan secepatnya diganti dengan tanaman yang baru. Reboisasi lahan kritis di daerah bencana longsor di sekitarnya perlu dilakukan oleh masyarakat, Pemerintah Daerah, Perhutani, LSM dan lainnya.

Pengamatan curah hujan ini diperlukan karena curah hujan merupakan salah satu pemicu terjadinya bencana tanah longsor. Menurut Sipayung et al. (2014) bahwa nilai ambang curah hujan yang berpotensi menyebabkan longsor akan berbeda pada setiap daerah, dan akan berpengaruh lebih besar pada daerah yang rentan longsor dibandingkan dengan daerah yang tidak rentan longsor meskipun dengan curah hujan yang sama. Menurut Paimin et al. (2009), curah hujan yang perlu diwaspadai pada daerah rentan longsor adalah $>300 \mathrm{~mm} / 3$ hari. Adanya informasi curah hujan yang tepat dan kontinyu, diharapkan dapat menjadi dasar peringatan dini bagi masyarakat yang tinggal di daerah rentan longsor seperti di Dusun Tangkil, Desa Banaran, Kecamatan Pulung.

Lereng dengan kemiringan sangat curam akan meningkatkan potensi terjadinya tanah longsor, sehingga upaya mitigasi pada wilayah ini sangat diperlukan, salah satunya adalah dengan upaya mengurangi volume air hujan yang masuk ke dalam profil tanah (Susanti et al., 2017). Berkaitan dengan hal ini, Hardiyatmoko (2006) menyampaikan bahwa untuk meningkatkan stabilitas lereng perlu dilakukan dengan perubahan geometri lereng yaitu dengan pelandaian kemiringan lereng, seperti dengan pembuatan teras bangku, mengontrol drainase dan rembesan terutama drainase aliran permukaan dan bawah permukaan, pembuatan bangunan untuk stabilisasi, pembongkaran dan pemindahan material pada daerah rentan longsor, serta perlindungan permukaan tanah.

Perlu dilakukan peningkatkan kesadaran dan kesiapsiagaan masyarakat terhadap potensi longsor di daerahnya. Hal ini bisa dimulai dengan pengamatan kondisi lingkungan dan iklim, termasuk di dalamnya pengamatan terhadap kondisi fisik lahan dan curah hujan. Kesadaran masyarakat terutama peningkatan kewaspadaan pada saat musim hujan dengan intensitas yang tinggi sangat diperlukan. Penetapan jalur evakuasi yang tepat juga berpengaruh terhadap proses penyelamatan warga apabila terjadi bencana longsor (Susanti et al, 2017). Masyarakat di sekitar daerah bencana perlu melakukan kontrol terhadap tanda-tanda gerakan tanah (adanya retakan, keluarnya mata air baru, mata air keruh, pohon-pohon miring, suara gemuruh dalam tanah) serta mewaspadai apabila terjadi pembendungan aliran sungai (waduk alam) di sepanjang aliran sungai. Masyarakat di sekitar bencana perlu waspada dan disarankan untuk mengungsi ke lokasi yang aman, karena daerah bencana dan sekitarnya masih berpotensi terjadi longsor susulan (PVMBG, 2017).

Material hasil longsoran di Sungai Tangkil merupakan material yang tidak terkonsolidasi dengan baik dan tidak stabil sehingga masih mudah bergerak apabila bercampur air dalam jumlah besar.Pembendungan pada Sungai Tangkil oleh material longsoran bisa terjadi dan berpotensi terjadinya banjir bandang.Untuk itu di sepanjang sungai tersebut harus dibebaskan terhadap permukiman.

Sistem peringatan dini bencana tanah longsor perlu untuk dibangun di daerah tersebut, baik yang berbasis masyarakat lokal maupun dengan instrumentasi.Peringatan dini berbasis masyarakat yang sudah terbangun perlu untuk diperkuat, dengan memanfaatkan sumberdaya yang ada di masyarakat. Sementara peringatan dini bencana tanah longsor dengan teknologi instrumentasi bisa berdasarkan pada tingginya curah hujan yang diukur oleh Auto Weather Station (AWS), ekstenseometer, kejenuhan tanah (soil moisture), tinggi muka airtanah (groundwater level recorder), inklinometer, akselerometer dan lainnya. 


\section{Kesimpulan}

Jenis longsoran pada daerah penelitian adalah longsoran bahan rombakan dan berkembang menjadi aliran bahan rombakan akibat bercampur dengan massa air. Material hasil longsoran di Sungai Tangkil tidak kompak sehingga masih mudah bergerak, dan berpotensi terjadinya aliran bahan rombakan atau banjir bandang.

Mekanisme terjadinya longsor adalah: batuan breksi vulkanik yang membentuk pelapukan tanah sangat tebal. telah membentuk perbukian yang sangat curam, terbentuk rekahan/retakan sebelum longsor, air hujan akibat curah hujan tinggi masuk melalui rekahan maupun melalui proses infiltrasi biasa kemudian menjenuhkan tanah penutup yang gembur sehingga keseimbangan tanah menjadi labil dan terbentuk kejadian tanah longsor dari tanah penutup beserta tanaman di atasnya melalui batuan breksi yang keras tersebut sebagai bidang gelincir.

Berdasarkan hasil analisis, faktor-faktor utama yang berpengaruh terhadap bencana tanah longsor yaitu :kelerengan yang sangat curam, batuan breksi vulkanik yang membentuk soil hasil pelapukan sangat tebal, alih fungsi lahan dengan tanaman hortikultura yang memerlukan upaya penggemburan tanah dan mengganggu kestabilan lereng, serta curah hujan yang tinggi.

Pada kawasan rawan longsor perlu dijadikan lahan perkebunan dengan tanaman keras yang berakar kuat dan dalam yang berfungsi dapat menahan lereng.Pertanian lahan kering pada lereng-lereng sebaiknya menggunakan pola agroforestry. Kawasan sub DAS berisiko longsor, sebaiknya dikembalikan fungsi lahan sebagai hutan konservasi atau hutan lindung seperti sebelumnya.

Beberapa permukiman yang mempunyai risiko tinggi dan sedang terhadap longsor, perlu dibangun peningkatan kesiapsiagaan masyarakat, pemasangan sistem peringatan dini longsor serta untuk jangka panjang adalah relokasi pada daerah yang aman jika memang kondisi semakin parah.

\section{DAFTAR PUSTAKA}

Damanik, M. R. S., \& Restu, R. 2012. Pemetaan Tingkat Risiko Banjir dan Longsor Sumatera Utara Berbasis Sistem Informasi Geografis. Jurnal Geografi, 4(1): pp. 29-42.

Hardiyatmoko, H. C. 2006. Penanganan Tanah Longsor dan Erosi (Edisi 1). Yogyakarta: Gadjah Mada University Press.

LAPAN, 2017, Citra SPOT-6 dengan tanggal akuisisi 23 Februari 2017.

Pareta, K. \& Pareta, U. 2012. Landslide Modeling and Susceptibility Mapping of Giri River. International Journal of Science and Technology, Vol. 1 No. 2, 2012: pp. 91-104.

Naryanto, H.S. 2017. Analisis Kejadian Bencana Tanah Longsor di Dusun Jemblung, Desa Sampang, Kecamatan Karangkobar, Kabupaten Banjarnegara, Provinsi Jawa Tengah tanggal 12 Desember 2014. Jurnal Alami, Vol. 1 No. 1 tahun 2017: pp. 1-10.
Naryanto, H.S. 2013. Analisis dan Evaluasi Kejadian Bencana Tanah Longsor di Cililin, Kabupaten Bandung Barat, Provinsi Jawa Barat Tanggal 25 Maret 2013, JSTMB, Vol. 8, No. 1, Tahun 2013: pp. 39-49.

Naryanto, H.S. 2011. Analisis Risiko Bencana Tanah Longsor di Kabupaten Karanganyar, Provinsi Jawa Tengah. Jurnal Penanggulangan Bencana, BNPB, Vol 2 No. 1 Tahun 2011: pp. 21-32.

Naryanto, H.S., Kristijono, A., Suwandita, H., Ganesha, D., Prawiradisastra, F. dan Udrekh. 2017. Analisis Kejadian Bencana Tanah Longsor (Gerakan Tanah) di Dusun Tangkil, Desa Banaran, Kecamatan Pulung, Kabupaten Ponorogo, Provinsi Jawa Timur Tanggal 1 April 2017. Laporan Kajian Cepat, PTRRB, BPPT.

Naryanto, H.S., Wisyanto, Sumargana, L., Ramadhan, R. dan Prawiradisastra, S. 2016. Kajian Kondisi Bawah Permukaan Kawasan Rawan Longsor dengan Geolistrik untuk Penentuan Lokasi Penempatan Instrumentasi Sistem Peringatan Dini Longsor di Kecamatan Talegong, Kabupaten Garut. Jurnal Riset Kebencanaan Indonesia (JRKI), Vol. 2 No. 2, Oktober 2016: pp. 161-172.

Paimin, Sukresno dan Pramono, I. B. 2009. Teknik Mitigasi Banjir dan Tanah Longsor. Balikpapan: Tropenbos International Indonesia Programme.

PVMBG. 2017. Laporan Singkat Pemeriksaan Gerakan Tanah Di Kecamatan Pulung, Kabupaten Ponorogo Provinsi Jawa Timur. [terhubung berkala]. http://www.vsi.esdm.go.id/index.php/gerakantanah/kejadian-gerakan-tanah/1519-laporan-singkatpemeriksaan-gerakan-tanah-di-kecamatan-pulungkabupaten-ponorogo-provinsi-jawa-timur.

PVMBG. 2009. Peta Zona Kerentanan Gerakan Tanah Kabupaten Ponorogo, Provinsi Jawa Timur. Badan Geologi, Kementerian ESDM.

Sampurno \& Samodra, H. 1997. Peta Geologi Lembar Ponorogo, Jawa, Skala 1 : 100.000. Pusat Penelitian dan Pengembangan Geologi.

Sipayung, S. B., Cholianawati, N., Susanti, I., Aulia, S., Edy, R., Pusat, P., \& Atmosfer, T. 2014. Pengembangan Model Persamaan Empiris Dalam Memprediksi Terjadinya Longsor di Daerah Aliran Sungai (DAS) Citarum (Jawa Barat) Berbasis Data Satelit TRMM. Jurnal Sains Dirgantara, 12(1): pp. 12-21.

Susanti, P.D., Miardini, A. dan Harjadi, B. 2017. Analisis Kerentanan Tanah Longsor Sebagai Dasar Mitigasi di Kabupaten Banjarnegara. Jurnal Penelilian Pengelolaan Daerah Aliran Sungai. Vol. 1 No. 1, April 2017: pp. 49-59.

Pareta, K. \& U. Pareta, 2012. Landslide Modeling and Susceptibility Mapping of Giri River Watershed, Himachal Pradesh (India). International Journal of Science and Technology Volume 1 No. 2, February, 2012: pp. 91-104.

Rahmad, R., Suib dan Nurman, A. 2018. Aplikasi SIG untuk Pemetaan Tingkat Ancaman Longsor di Kecamatan Sibolangit, Kabupaten Deli Serdang, Sumatera Utara. Majalah Geografi Indonesia, Vol. 32, No.1, Maret 2018: pp. 1-13.

Wang, F., Xu, P., Wang, C., Wang, N., \& Jiang, N. 2017. Application of a GIS Based Slope Unit Method for Landslide Susceptibility Mapping along the Longzi River, Southeastern Tibetan Plateau, China. ISPRS International Journal of Geo-Information, 6(6): pp. 172.

Yuniarta, H., Saido, A.P., \& Purnama, Y.M. 2015. Kerawanan Bencana Tanah Longsor Kabupaten Ponorogo. E-Jurnal Matriks Teknik Sipil, Maret 2015: pp. 194-201.

Zuidam, R.A.V. 1985. Aerial Photo-Interpretation in Terrain Analysis and Geomorphologic Mapping. ITC, Smits Publ., Enschede, The Hague. 